\title{
Cheatgrass invasion alters the abundance and composition of dark septate fungal communities in sagebrush steppe
}

\begin{tabular}{|r|l|}
\hline Journal: & Botany \\
\hline Manuscript ID & cjb-2015-0237.R1 \\
\hline Danuscript Type: & Article \\
\hline Complete List of Authors: & $\begin{array}{l}\text { Gehring, Catherine; Northern Arizona University, Department of Biological } \\
\text { Sciences and the Merriam-Powell Center for Environmental Research } \\
\text { Hayer, Michaela; Northern Arizona University, Department of Biological } \\
\text { Sciences and the Center for Ecosystem Science and Society } \\
\text { Flores-Renteria, Lluvia; Western Sydney University, Hawkesbury Institute } \\
\text { for the Environment; Northern Arizona University, Department of Biological } \\
\text { Sciences and the Merriam-Powell Center for Environmental Research } \\
\text { Krohn, Andrew; Northern Arizona University, Department of Biological } \\
\text { Sciences and the Merriam-Powell Center for Environmental Research } \\
\text { Schwartz, Egbert; Northern Arizona University, Department of Biological } \\
\text { Sciences and the Center for Ecosystem Science and Society } \\
\text { Dijkstra, Paul; Northern Arizona University, Department of Biological } \\
\text { Sciences and the Center for Ecosystem Science and Society }\end{array}$ \\
\hline Keyword: & $\begin{array}{l}\text { dark septate fungi, invasive species, cheatgrass, sagebrush steppe, } \\
\text { Pleosporales }\end{array}$ \\
\hline & \multicolumn{1}{|c|}{} \\
\hline
\end{tabular}


Cheatgrass invasion alters the abundance and composition of dark septate fungal communities in sagebrush steppe

Catherine A. Gehring ${ }^{1,4}$, Catherine.Gehring@nau.edu

Michaela Hayer ${ }^{2,4}$, Michaela.Hayer@nau.edu

Lluvia Flores-Rentería ${ }^{1,3}$ L.FloresRenteria@uwswesternydney.edu.au

Andrew F. Krohn', alk224@nau.edu

Egbert Schwartz², Egbert.Schwartz@nau.edu

Paul Dijkstra², Paul.Dijkstra@nau.edu

${ }^{1}$ Department of Biological Sciences and the Merriam-Powell Center for Environmental

Research, Northern Arizona University, Flagstaff, AZ 86011

${ }^{2}$ Department of Biological Sciences and the Center for Ecosystem Science and Society, Northern Arizona University, Flagstaff, AZ 86011

${ }^{3}$ Hawkesbury Institute for the Environment, Western Sydney University, Locked Bag 1797 , Penrith, NSW 2751, Australia

${ }^{4}$ joint first authors

Corresponding Author: Michaela Hayer, Center for Ecosystem Science and Society, Northern Arizona University, Flagstaff, AZ, USA, telephone number: (928) 523-2393, e-mail address:

Michaela.Hayer@nau.edu 
Abstract: Invasive, non-native plant species can alter soil microbial communities in ways that contribute to their persistence. While most studies emphasize mycorrhizal fungi, invasive plants also may influence communities of dark septate fungi (DSF), common root endophytes that can function like mycorrhizas. We tested the hypothesis that a widespread invasive plant in the western United States, cheatgrass (Bromus tectorum), influenced the abundance and community composition of DSF by examining the roots and rhizosphere soils of cheatgrass and two native plant species in cheatgrass invaded and non-invaded areas of sagebrush steppe. We focused on cheatgrass because it is negatively affected by mycorrhizal fungi and colonized by DSF. We found that DSF root colonization and operational taxonomic (OTU) richness were significantly higher in sagebrush (Artemisia tridentata) and rice grass (Achnatherum hymenoides) from invaded areas than non-invaded areas. Cheatgrass roots had similar levels of DSF colonization and OTU richness as native plants. The community composition of DSF varied with invasion in the roots and soils of native species and among the roots of the three plant species in invaded areas. The substantial changes in DSF we observed following cheatgrass invasion argue for comparative studies of DSF function in native and non-native plant species.

Keywords: dark septate fungi, invasive species, cheatgrass, sagebrush steppe, Pleosporales 


\section{Introduction}

Invasive, non-native species are a significant ecological and economic concern because of the changes they cause to community structure and ecosystem processes in natural and managed ecosystems (Mack et al. 2000, Ehrenfeld 2003, Pimentel et al. 2005, Lodge et al. 2006). Recent research demonstrates that invasive plant species can alter the abiotic and biotic characteristics of the soil and that these changes can feed back to affect their establishment, competitive ability, and persistence (Klironomos 2002, Bever 003,Vogelsang and Bever 2009, Pringle et al. 2009). Soil carbon and nutrient pools are frequently modified by invasive species (Ehrenfeld 2003, Tamura and Tharayil 2014), while species like garlic mustard (Alliaria petiolata) produce allelochemicals that negatively affect the root-associated arbuscular mycorrhizal fungi (AMF) upon which many native plant species depend for soil resource uptake (Stinson et al. 2006). Bacterial endophytes recruited from the soil contributed to the competitive ability of Sorghum halapense in tallgrass prairie and were passed onto offspring via seeds (Rout et al. 2013). Increases in the abundance and changes in the community composition of dark septate fungi (DSF) have been observed following invasion by two widespread non-native plants in the western United States, tamarisk (Tamarix spp) in riparian areas (Meinhardt and Gehring 2012, Hultine et al. 2015) and cheatgrass (Bromus tectorum L.) in sagebrush steppe (Goldberry and Deckert 2006, Weber et al. 2015).

Dark septate fungi are a diverse, polyphyletic group of ascomycete fungi that colonize the healthy root tissue of numerous plant species with characteristic highly-melanized, septate hyphae (Jumpponen and Trappe 1998, Jumpponen 2001, Mandyam and Jumpponen 2005). The distribution and function of DSF remains poorly understood but they appear to be of particular importance in stressful environments such as alpine, saline and arid ecosystems (Newsham et al. 2011, Porras-Alfaro et al. 2011, Knapp et al. 2012). Their effects on host plants range from 
positive to negative depending upon plant species or genotype, fungal species or strain and environmental factors (Gehring et al. 2014, Mandyam and Jumpponen 2014). In ecosystems where nitrogen is present largely in organic form, DSF tend to function similarly to mycorrhizal mutualists, improving the nutrient uptake and growth of their hosts (Newsham 2011). Dark septate fungi are hypothesized to facilitate nutrient translocation between biological soil crusts and plants in arid grasslands (Collins et al. 2008, Porras-Alfaro et al. 2011). Disturbances in these grasslands, such as fire and subsequent invasion by non-native plants, could cause declines in DSF, potentially altering nutrient translocation. However, in sites dominated by non-native tamarisk, reductions in the abundance of arbuscular mycorrhizal and ectomycorrhizal fungi of native Populus fremontii are accompanied by increases in DSF, the predominant root associated fungi observed in Tamarix (Meinhardt and Gehring 2012). Other non-native plants also cause reductions in mycorrhizal fungal abundance and diversity (e.g., Stinson et al. 2006, Owen et al. 2013), but their effects on DSF remain poorly studied.

Cheatgrass is a rapidly expanding non-native, annual $\mathrm{C}_{3}$ grass that is a poor host for arbuscular mycorrhizal fungi (Goldberry and Deckert 2006, Owen et al. 2013) but can form associations with DSF (Goldberry and Deckert 2006). Cheatgrass originated from Eurasia and has now displaced native plants from over 20 million hectares of the western United States (Duncan et al. 2004). Cheatgrass invasion is associated with shifts in soil microbial communities and associated nutrient cycling processes (Belnap and Phillips 2001, Kuske et al. 2002, Norton et al. 2004) as well as changes in the abundance and species composition of arbuscular mycorrhizal fungi in roots and soil (Hawkes 2006, Owen et al. 2013, Busby et al. 2013). Recently, Weber et al. (2015) documented striking differences at the order level between the soil fungal communities of adjacent cheatgrass and sagebrush dominated sites. One of the major lineages forming DSF, the Pleosporales, were common, but varied in composition as a function of dominant plant 
species and soil depth. Weber et al. (2015) suggested that further study of the Pleosporales in association with cheatgrass invasion was needed, particularly studies that included native grass species.

In this study, we investigated the abundance, species richness and community composition of DSF in cheatgrass and sagebrush-dominated ecosystems using next generation sequencing analysis of the roots and rhizosphere soils of big sagebrush (Artemisia tridentata Nutt. ssp. wyomingensis Beetle and Young) and a perennial native grass, Indian rice grass (Achnatherum hymenoides (Roemer \& J.A. Schultes. Barkworth), in areas dominated by either cheatgrass or sagebrush. We made the same measurements on cheatgrass, which only occurred in the cheatgrass dominated areas. Although we obtained data on other fungi as part of our DNA sequencing, we focused this study on members of the order Pleosporales, the only recognized order of DSF we observed. We tested the following hypotheses:

H1. Colonization of roots by DSF varies with dominant plant association (cheatgrass-dominated versus sagebrush-dominated vegetation) and plant species (cheatgrass, sagebrush and rice grass). Given that cheatgrass biomass was negatively associated with colonization by arbuscular mycorrhizal fungi (Scherpenisse 2009, Owen et al. 2013), and that habitats dominated by nonnatives can be associated with greater abundance of DSF (Meinhardt and Gehring 2012), we predicted that DSF colonization would be higher in invaded (cheatgrass dominated) than noninvaded (sagebrush dominated) sites and highest within cheatgrass roots.

H2. DSF root communities represent a subset of DSF soil communities. Determining if and how root and soil communities vary from one another is important for understanding the function of the poorly described species of fungi characteristic of arid lands (Porras-Alfaro et al. 2011, Busby et al. 2013). 
H3. Invasion by cheatgrass alters the DSF community composition and reduces species richness in the roots and rhizosphere soil of a native grass and a native shrub. The low AMF colonization and species richness characteristic of cheatgrass roots may favor root colonization by DSF in cheatgrass. Dark septate fungi may become more abundant than AMF in the soil resulting in greater diversity and altered species composition of DSF in the roots of native plants in invaded sites relative to non-invaded sites.

H4. When growing together in an invaded site, the root and soil DSF communities of rice grass sagebrush, and cheatgrass will differ significantly from one another. We expect non-native cheatgrass to have a different community of DSF than its native neighbors because of its negative relationship with the other dominant root associates in the system, AMF. We expect rice grass and sagebrush communities to differ because DSF may associate more strongly with grasses in semi-arid systems (Porras-Alfaro et al 2011, Knapp et al. 2012). Previous studies of DSF associated with the root and soil communities of sagebrush ecosystems converted to cheatgrass have compared only sagebrush and cheatgrass roots and soil (Weber et al. 2015), leaving open the question of impacts on native grass DSF.

\section{Materials and Methods}

We tested these hypotheses by sampling roots and rhizosphere soils on November 15, 2013 within a 990 ha study area located in the Kaibab National Forest in northern Arizona at $\sim 1800 \mathrm{~m}$ elevation $(36.625,-112.523)$. The study area occupied a mixed shrubland/woodland community within areas burned in the 1996 Bridger-Knoll Complex wildfire. The Bridger-Knoll fire burned more than 20,000 ha of pinyon-juniper and mixed shrub communities (USDA Burned-Area Report 1996). In addition to rice grass and big sagebrush, common native plants included Mormon tea (Ephedra viridis Coville), two needle pinyon (Pinus edulis Engelm.) and Utah 
juniper (Juniperus osteosperma (Torr.) Little). Long-term mean annual precipitation in the area averaged $379 \mathrm{~mm}$ and the mean annual temperature averaged $12.4^{\circ} \mathrm{C}$ (years 1976 to 2009 ; WRCC 2009). Soils in the area are classified as Mellenthin series, derived from Kaibab limestone and sandstone, a mix of loamy-skeletal, mixed, superactive, mesic Lithic Ustic Haplocalcids (Owen et al. 2011).

We sampled the roots and root-associated (rhizosphere) soil of sagebrush, cheatgrass, and rice grass plants in two types of locations in the study area, cheatgrass-dominated (hereafter called "invaded") and sagebrush dominated (hereafter called "non-invaded"). Visual assessments along ten linear transects across the study area indicated that the invaded areas contained all three focal plant species, with cheatgrass dominating and sagebrush and rice grass occurring at lower density. Cheatgrass was absent from the "non-invaded" areas, which were dominated by sagebrush. Rice grass abundance was similar across the landscape. Because a large area of land was included in our sampling, the focal plant species were sampled in "sets" in which individual replicate samples of each plant species were collected within $7 \mathrm{~m}$ of one another. Six sets of three species were sampled in the invaded area (in total 18 root and 18 rhizosphere soil samples), and six sets of two species of plant were sampled in the native area (in total 12 root and 12 soil samples). Roots were excavated with a trowel and traced to the focal plant; soil adhering to the roots was shaken off and placed in a $50 \mathrm{ml}$ falcon tube and roots were stored in polyethylene bags. Root and soil samples were stored at $-20^{\circ} \mathrm{C}$ until processing. Although cheatgrass is known for its early spring flowering (Knapp 1996), it reproduces twice annually in the study area, once in the spring and then again after summer rains that begin in July (Owen et al. 2011). Both grass species had completed flowering, but were still green with abundant living roots at the time of sampling. 
In the laboratory, root samples were thoroughly washed in tap water and rinsed in distilled water. A random subset of roots from each sample was cleared for $20 \mathrm{~min}$ in boiling $10 \% \mathrm{KOH}$ and then left an additional $12 \mathrm{~h}$ at room temperature in fresh $10 \% \mathrm{KOH}$. Roots were rinsed in distilled water, mounted on slides and observed using a compound microscope at 400X magnification. The presence of melanized, septate hyphae and microsclerotia were used as indicators of DSF and quantified using the grid-line intersect method (McGonigle et al. 1990).

DNA extraction and amplicon sequencing

Total DNA was extracted from $0.5 \mathrm{~g}$ soil and $0.5 \mathrm{~g}$ of fine root tissue from each sample using the MoBIO PowerLyzer PowerSoil DNA extraction kit (MoBio Laboratories, Carlsbad, California, USA) following the manufacturer's instructions. DNA extractions were diluted to $2 \mathrm{ng} / \mu \mathrm{L}$ and used as template to amplify the internal transcribed spacer (ITS) region of the rDNA with the primers ITS7oF and ITS4R as described in Kohout et al. (2013). These primers amplify the hypervariable ITS2 region, which is commonly used as a DNA metabarcoding marker for fungi (Mello et al., 2011; Davey et al., 2012). The amplification was done in triplicate reactions containing $1 \mathrm{mM}$ of each primer, $0.01 \mathrm{U} / \mu \mathrm{L}$ Phusion HotStart II Polymerase (Thermo Fisher Scientific, Waltham Massachusetts, USA), 1X Phusion HF buffer (Thermo Fisher Scientific), 3 $\mathrm{mM} \mathrm{MgCl} 2,6 \%$ glycerol, and $200 \mu \mathrm{M}$ dNTPs. The PCR conditions involved an initial denaturation step at $94{ }^{\circ} \mathrm{C}$ for $4 \mathrm{~min}$, followed by 20 cycles of $94{ }^{\circ} \mathrm{C}$ for $30 \mathrm{sec}, 49{ }^{\circ} \mathrm{C}$ for $30 \mathrm{sec}$, and $72{ }^{\circ} \mathrm{C}$ for $90 \mathrm{sec}$. Products were checked on a $1 \%$ agarose gel, pooled, diluted 10 -fold, and used as template in the subsequent tailing reaction with region-specific primers including the Illumina flow cell adapter sequences and an 8 nucleotide barcode using the previously described PCR conditions. Products of the tailing reaction were purified with carboxylated SeraMag Speed 
Beads (Sigma-Aldrich, St. Louis, Missouri, USA) at a 1:1 v/v ratio as described in Rohland and Reich (2012), and quantified by PicoGreen fluorescence. Equal quantities of the reaction products were then pooled. The library was bead-purified once again (1:1 ratio), quantified by qPCR using the Library Quantification Kit for Illumina (Kapa Biosciences, Woburn, Massachussetts, USA), and loaded at 9 pM (including a 30\% PhiX control) onto an Illumina MiSeq instrument (Illumina, San Diego, California, USA) using 2 x 150 paired-end read chemistry. The flow cell produced $733+/-36 \mathrm{~K}$ clusters per $\mathrm{mm}^{2}$, returning over 12.5 million reads that passed the quality filter. All sequences have been deposited at GenBank, accession number SRP068514.

\section{Data analysis}

The forward and reverse reads were stitched using FastqJoin (Aronesty, 2011). ITS sequences were quality filtered with the software package Quantitative Insights into Microbial Ecology v 1.9 (QIIME) (Caporaso et al., 2010 a) using a Phred score cut-off value of 20. Fungal sequences were extracted using ITSx (Bengtsson-Palme et al, 2013), and OTUs were picked using SWARM (Mahe et al., 2014) with a local clustering threshold value of 3 . The most abundant sequence for each OTU was aligned with PyNAST (Caporaso et al., 2010 b) against the UNITE database (Abarenkov et al, 2010), using a 97\% similarity cutoff, and taxonomy was assigned using BLAST (Altschul et al., 1990). The OTU table was filtered to include DSF only, and rarefied to 180 sequences per sample. Dissimilarity matrices of community compositions based on the ITS2 amplicon data were calculated using Bray-Curtis. Principal coordinate analysis was performed on the dissimilarity matrices to visualize patterns of community composition.

PerMANOVA with 999 permutations was performed to compare plant root and rhizosphere soil DSF community composition of different plant species, and in invaded and non-invaded habitats. 
Species richness and DSF colonization were analyzed using ANOVA and Tukey's HSD post-hoc comparisons when appropriate. Cheatgrass only occurred in invaded areas, so two sets of PerMANOVA and ANOVA analyses were conducted. The first analysis compared the DSF of rice grass and sagebrush growing in invaded and non-invaded areas while the second analysis compared sagebrush, cheatgrass and rice grass DSF only in the invaded sites. We conducted indicator species analyses (ISAs) for invaded and non-invaded sites and for each plant species at the non-invaded site. Calculated indicator values (IVs) were assessed for statistical significance $(p \leq 0.05)$ using Monte Carlo randomizations with 999 permutations. Species were considered to be 'strong' indicators if the IV $>40$. Data analysis was performed in Primer v 6 (Clarke \& Gorley, 2006), PC-ORD 5 (McCune \& Mefford, 2011), and R (R Development Core Team, 2011).

\section{Results}

We found partial support for our first prediction that DSF colonization would be higher in invaded than non-invaded areas and highest within cheatgrass roots. Colonization by DSF was significantly higher in the invaded than non-invaded areas for both sagebrush and rice grass $\left(\mathrm{F}_{1,20}\right.$ $=10.50, \mathrm{P}=0.004)$, but the two species had similar levels of colonization $\left(\mathrm{F}_{1,20}=3.37, \mathrm{P}=0.08\right)$ and there was no significant plant species by site interaction $\left(\mathrm{F}_{1,20}=1.48, \mathrm{P}=0.23\right)(\mathrm{Fig} 1 \mathrm{~A})$. In the invaded areas, cheatgrass had significantly higher colonization by DSF than sagebrush, but not than rice grass $\left(\mathrm{F}_{2,15}=6.82, \mathrm{P}=0.008\right)($ Fig $1 \mathrm{~A})$.

After quality filtering we obtained 225,000 DSF sequences (fungi within the order Pleosporales) that clustered into 128 OTUs. The most common genera observed were Alternaria, Preussia, Phoma, Phaeosphaeria, and Venturia. OTUs that could not be identified beyond order 
(Pleosporales) or family (Pleosporaceae) were also common, making up $\sim 10 \%$ of the OTUs. Rarefaction analysis showed that a sampling depth of 180 sequences per sample (which ranged from $180-15,000)$ provided asymptotic estimates of species richness (Fig 2). Average OTU richness was lower in root samples than in soil samples $\left(\mathrm{F}_{1,42}=16.0, \mathrm{P}<0.0002\right)$ (Fig.2). On average we observed 10.5 OTUs in the root samples and 17.8 OTUs in the soil samples. Thirtyeight OTUs were unique to the soil samples, while 36 OTUs were unique to the root samples, and 54 OTUs occurred in both samples types (Fig 2, inset). The lower species richness of the root community is consistent with our hypothesis $(\mathrm{H} 2)$ that the root DSF community represents a subset of the soil DSF community, but the large number of OTUs unique to root samples is not.

In support of our third hypothesis, soil and root DSF communities of sagebrush and rice grass varied with cheatgrass invasion. OTU composition differed significantly between invaded and non-invaded sites for both soil and root samples (pseudo- $\mathrm{F}_{1,22}=5.2, \mathrm{P}=0.001$ and pseudo$\mathrm{F}_{1,21}=2.9, \mathrm{P}=0.001$, respectively) (Fig. 3). The two plant species did not differ significantly from one another in either root $\left(p^{2}\right.$ udo- $\left.\mathrm{F}_{1,22}=1.7 \mathrm{P}=0.09\right)$ or soil $\left(\mathrm{PCoA}\right.$, pseudo- $\mathrm{F}_{1,22}=1.0, \mathrm{P}$ $=0.50)$ samples. There was also no significant interaction between plant species and site type for roots (pseudo- $\mathrm{F}_{1,22}=1.6, \mathrm{P}=0.14$ ) or soil (pseudo- $\mathrm{F}_{1,22}=1.8 \mathrm{P}=0.08$ ). Dark septate fungi OTU richness in roots was significantly higher in the invaded habitats $\left(\mathrm{F}_{1,22}=9.2 \mathrm{P}=0.006\right.$; Fig. 1B), but there was no effect of invasion on the OTU richness of rhizosphere soil $\left(\mathrm{F}_{1,21}=0.4\right.$ $\mathrm{P}=0.54$; Fig 1C). Some of the differences in root communities were striking. For example, a member of the genus Preussia was more than fifty times more abundant in sagebrush and rice grass roots in the non-invaded areas than the invaded areas. Indicator species analysis identified this OTU as an indicator of sagebrush roots in the non-invaded site. We also determined four indicator species for non-invaded soils, Macrospora scirpicola, Westerdykella ornate, Pleosporales sp and Venturia fraxini. Seven OTUs were indicators for invaded sites in roots and 
six OTUs were indicators for invaded sites in soils. Five of these OTUs, were strong indicators of both roots and soil (Table 1).

Root DSF communities in the invaded habitat varied among the three plant species (pseudo- $\mathrm{F}_{2,17}=3.9, \mathrm{P}=0.001$ ), supporting our hypothesis $(\mathrm{H} 4)$. Sagebrush root communities differed significantly from both cheatgrass and rice grass communities (pairwise test $\mathrm{P}=0.001$, 0.005, respectively), which also differed from each other $(\mathrm{P}=0.013)($ Fig. 4$)$. We identified a single species, Conitohyrium nitidae, as an indicator of sagebrush roots, and an uncultured Pleosporales as an indicator of cheatgrass roots. Indicator species analysis also identified two indicators for rice grass roots, Leptosphaerulina chartarum, and a Pleosporales sp (Table 1). Dark septate fungi OTU richness did not vary significantly among plant species in the roots $\left(\mathrm{F}_{2,17}\right.$ $=2.1, \mathrm{P}=0.15)$. Soil DSF richness or community composition also did not vary among plant species $\left(F_{2,16}=1.7, P=0.21\right.$ and $\left.F_{2,16}=0.8, P=0.70\right)($ Fig. 4$)$.

\section{Discussion}

Our observation that levels of root colonization by DSF were higher in association with an invasive plant and in native plant species in invaded areas is consistent with previous studies. Similar to our results, native cottonwoods (Populus fremontii) growing in association with nonnative tamarisk had reduced colonization by mycorrhizal fungi and higher colonization by DSF than cottonwoods with conspecific neighbors (Meinhardt and Gehring 2012). Native Tanacetum vulgare had higher colonization by DSF in soils conditioned by invasive Solidago canadensis than by conspecifics (Schittko and Wurst 2014). Several other studies document that cooccurring native and non-native plants species harbor DSF, but few of them report percentage root length colonized. Knapp et al. (2012) observed DSF in the roots of eight native plant species and three non-native plant species in semiarid grassland and woody steppe habitats on 
the Great Hungarian Plain. Other studies focus solely on non-native plants. A survey of 37 nonnative plant species in Europe observed variable, but overall low levels of colonization by DSF (Majewska et al. 2015) while fewer species of weeds were colonized by DSF than by AMF in Brazil (Massenssini et al. 2014). These latter studies suggest that non-native plant species are frequently colonized by DSF, but they do not address the question of higher colonization in habitats dominated by non-native plants or in non-native compared to native plant species. Interestingly, in our study and the study on tamarisk invasion, the non-native plant species were either nonmycorrhizal (tamarisk, Meinhardt and Gehring 2012) or were negatively affected by inoculation with mycorrhizal fungi (cheatgrass, Scherpenisse 2009, Owen et al. 2013). The function of DSF in native and invasive plants may be particularly important where the mycorrhizal dependency of the invasive plant species is low. This may be a common feature of invasive plants in the United States given the analysis by Pringle et al. (2009) showing that a greater proportion of the non-native flora of California belonged to nonmycorrhizal families than the native flora.

The genera of fungi observed to dominate the Pleosporalean DSF communities in our study are similar to those observed in other semi-arid landscapes. Members of the genera Alternaria, Preussia, Leptosphaeria and Phaeosphaeria were also common in semi-arid grassland in New Mexico (Khidir et al. 2010, Porras-Alfaro et al. 2011). The DSF associated with eleven species of plants intensively studied on the Hungarian Plain also included many members of the Pleosporales, the only order of DSF in our study. Taxa of DSF from Hungary also overlapped with those observed in New Mexico and the North American prairie (Knapp et al. 2012). These similarities in taxon composition across studies provide support for the hypothesis that many DSF are host generalists and that non-native plants will find compatible fungi upon entering novel landscapes (Knapp et al. 2012). 
We hypothesized that the root DSF community would be a subset of the soil community, indicating that the root associated community is recruited from the pool of soil fungi. Carter et al. (2014) found that young sagebrush plants had similar root AMF communities as the surrounding soil. This was not what we observed for the DSF community, however, as root and soil communities shared only 54 out of 128 OTUs, with an additional one third of the OTUs only detected in the roots. A similar result has previously been described in AMF (Busby et al 2013, Saks et al 2014) and DSF (Porras-Alfaro et al. 2011), and indicates that sampling of rhizosphere soil, even soil directly attached to roots, does not provide a good picture of the fungi involved in plant-fungal symbioses. One explanation for this observation is the low abundance of fungi in soils compared to roots (Saks et al. 2014). Rare organisms, due to low concentration of their DNA in a sample, may not be captured during amplicon sequencing. Another explanation is that some DSF do not live in rhizosphere soils. Although DSF are generally transmitted horizontally (Herrera et al 2010), many endophytes are transmitted vertically via seeds (Siegel et al. 1985, Baker and Smith, 1966) and do not live outside plant tissues. The discrepancy we observed between rhizosphere soil and root-associated communities is important and should be considered when designing experiments that look at the effects of plants on fungal communities or the effects of the environment on plant associated fungal communities.

Sagebrush and rice grass root DSF communities were more species rich in invaded than non-invaded areas, but similar patterns were not observed in the soil. The difference in OTU richness with cheatgrass invasion was particularly striking for sagebrush roots with an average OTU richness in non-invaded, sagebrush dominated sites of less than six compared to an OTU richness nearly double that in the invaded areas. These differences may be linked to variation in the abundance or diversity of AMF in areas dominated by cheatgrass. Sagebrush and rice grass tend to be highly colonized by AMF (Bethlenfalvay and Dakessian 1984, Duke et al. 1994) while 
cheatgrass colonization by AMF is low and its growth is negatively affected by AMF (Scherpenisse 2009, Lekberg et al. 2012, Owen et al. 2013). Cheatgrass had lower AMF richness than sagebrush where they co-occurred in Idaho (Busby et al. 2013), but DSF richness was not measured. Arbuscular mycorrhizal fungi and other root endophytes like DSF can interact negatively (Rillig et al. 2013, Gehring et al. 2014), potentially due to root exudates produced by DSF (Scervino et al. 2014). Over time, cheatgrass invasion could result in reduced abundance and species richness of AMF and corresponding increases in other fungi such as DSF that may colonize roots in the place of AMF. The consequences of these changes are important to evaluate for both cheatgrass and native plants, particularly given that DSF impacts on host plants vary from mutualism to parasitism (Mandyam and Jumpponen 2014). Also, because our study was limited in temporal and spatial scope, it is important to determine if the patterns we observed are also found in other areas of sagebrush steppe invaded by cheatgrass.

In addition to changes in OTU richness, the OTU composition of roots and rhizosphere soils of native plants differed between cheatgrass and sagebrush dominated areas. Cheatgrass, sagebrush and rice grass root DSF communities also differed from one another, similar to several studies of AMF in which neighboring plants had distinct root communities (Vandenkoornhuyse et al. 2002, Rosendahl et al. 2004). Our findings with cheatgrass invasion are consistent with studies of soil from cheatgrass invaded and sagebrush dominated plots in Idaho where several orders of fungi, including the Pleosporales, varied with vegetation type (Weber et al. 2015). In our study, two species of Alternaria were indicators of both the root and soil communities of invaded areas, while an undescribed member of the genus Preussia was a strong indicator of root DSF communities in the sagebrush dominated site. Other, poorly known fungi were indicators of sagebrush, cheatrgrass and rice grass in the cheatgrass dominated site (unknown Pleosporales, Westerdykella and Coniothyrium). Members of the genus Alternaria are known as opportunistic 
plant pathogens, decomposers, and endophytes so their function in cheatgrass invaded areas is hard to predict. Westerdykella and Preussia can be decomposers associated with dung and soil or endophytes (Ebead et al. 2012). Alternaria, Preussia and Westerdykella produce a range of secondary metabolites with antimicrobial properties (Mousa and Razaida 2013, Mapperson et al. 2014) and are thus likely to influence the abundance of other microbes in roots and soil. Mousa and Razaida (2013) suggested that many of the secondary metabolites produced by endophytic fungi target the pathogens of their host plants, an important hypothesis to test in both native and invasive plant species.

In conclusion, we found that the presence of an invasive grass strongly influenced the abundance, diversity and OTU composition of root-associated DSF, a result consistent with previous work on these widespread but poorly understood fungi. Taken together, these studies suggest an additional effect of invasive plants on the soil biota that merits further investigation.

\section{Acknowledgements}

We thank M. Scott for assistance in the laboratory, E. and M. Allen and members of the Gehring/Haubensak Lab Group for helpful comments on data presentation, and B. Betenson for help accessing field sites. We also want to thank two anonymous reviewers for improving this manuscript. This research was supported wholly by the U.S. Department of Defense, through the Strategic Environmental Research and Development Program (SERDP - RC 2327). 


\section{References}

Abarenkov, K., Nilsson, R.H., Larsson, K.-H., Alexander, I.J., Eberhardt, U., Erland, S., Høiland, K., Kjøller, R., Larsson, E., Pennanen, T., Sen, R., Taylor, A.F.S., Tedersoo, L., Ursing, B.M., Vrålstad, T., Liimatainen, K., Peintner, U., and Koljalg, U. 2010. The UNITE database for molecular identification of fungi - recent updates and future perspectives. New Phytologist 186(2): 281-285. doi: 10.1111/j.1469-8137.2009.03160.

Altschul, S.F., Gish, W., Miller, W., Myers, E.W., and Lipman, D.J. 1990. Basic local alignment search tool. Journal of Molecular Biology. 215(3): 401-410. doi: 10.1016/S00222836(05)80360-2.

Erik Aronesty. 2011. ea-utils : Command-line tools for processing biological sequencing data. http://code.google.com/p/ea-utils

Baker, K. F., and Smith, S.H. 1966. Dynamics of seed transmission of plant pathogens. Annual Review of Phytopathology 4(1): 311-332.

Belnap, J., and Phillips, S.L. 2001. Soil biota in an ungrazed grassland: response to annual grass (Bromus tectorum) invasion. Ecological applications 11(5): 1261-1275.

Bengtsson-Palme, J., Ryberg, M., Hartmann, M., Branco, S., Wang, Z., Godhe, A., De Wit, P., Sánchez-García, M., Ebersberger, I., de Sousa, F., Amend, A.S., Jumpponen, A., Unterseher, M., Kristiansson, E., Abarenkov, K., Bertrand, Y.J.K., Sanil, K., Eriksson, K.M., Vik, U., Veldre, V., and Nilsson, R.H. 2013. Improved software detection and extraction of ITS1 and ITS2 from ribosomal ITS sequences of fungi and other eukaryotes for analysis of environmental sequencing data. Methods in Ecology and Evolution 4(10): 914-919. 
doi: 10.1111/2041-210X.12073.

Bever, JD. 2003. Soil community feedback and the coexistence of competitors: conceptual frameworks and empirical tests. New Phytologist 157(3): 465-473. doi: 10.1046/j.14698137.2003.00714.x.

Bethlenfalvay, G.J. and Dakessian, S. 1984. Grazing effects on mycorrhizal colonization and floristic composition of the vegetation on a semiarid range in northern Nevada. Journal of Range Management 37: 312-316.

Busby, R. R., Stromberger, M.E., Rodriguez, G., Gebhart, D.L., and Pascke, M.W. 2013. Arbuscular mycorrhizal fungal community differs between a coexisting native shrub and introduced annual grass. Mycorrhiza 23(2): 129-141. DOI 10.1007/s00572-012-0455-x

Caparaso, J.G., Kuczynski, J., Stombaugh, J., Bittinger, K., Bushman, F.D., Costello, E.K., Fierer, N., Gonzales Pena, A., Goodrich, J.K., Gordon, J.I., Huttley, G.A., Kelley, S.T., Knights, D., Koenig, J.E., Ley, R.E., Lozupone, C.A., McDonald, D., Muegge, B.D., Pirrung, M., Reeder, J., Svensky, J.R., Turnbaugh, P.J., Walters, W.A., Widman, J., Yatsunenko, T., Zaneveld, J., and Knight, R. 2010 a. QIIME allows analysis of high-throughput community sequencing data. Nature Methods 7(5):335-336. doi:10.1038/nmeth.f.303.

Caparaso, J.G., Bittinger, K., Bushman, F.D., Desantis, T.Z., Andersen, G.L., and Knight, R. 2010 b. PyNAST: a flexible tool for aligning sequences to a template alignment. Bioinformatics 26(2): 266-267. doi: 10.1093/bioinformatics/btp636

Carter, K.A., Smith, J.F., White, M.M., and Serpe, M.D. 2014. Assessing the diversity of arbuscular mycorrhizal fungi in semiarid shrublands dominated by Artemisia tridentata ssp. 
wyomingensis. Mycorrhiza 24(4): 301-314. doi: 10.1007/s00572-013-0537-4

Clarke, K.R., and Gorley, R.N. 2006. PRIMER v6: User Manual/Tutorial. PRIMER-E, Plymouth, 192pp.

Collins, S.L., Sinsabaugh, R.L., Crenshaw, C., Porras-Alfaro, A., Stursova, M., and Zeglin, L. 2008. The threshold-delay nutrient dynamics model for aridland ecosystem processes. J Ecol 96(3):413-420, doi:10.1111/j.1365-2745.

Davey, M. L., Heegaard, E., Halvorsen, R., Ohlsn, M., and Kauserud, H. 2012. Seasonal trends in the biomass and structure of bryophyte-associated fungal communities explored by 454 pyrosequencing. New Phytologist 195(4): 844-856. doi: 10.1111/j.1469-8137.2012.04215.x

Duke, S. E., Jackson, R.B, and Caldwell, M.M. 1994. Local reduction of mycorrhizal arbuscule frequency in enriched soil microsites. Canadian Journal of Botany 72(7): 998-1001.

Ebead, G.A., Overy, D.P., Berrué, F., and Kerr, R.G. 2012 Westerdykella reniformis sp. nov., producing the antibiotic metabolites melinacidin IV and chetracin B. IMA Fungus. 3(2):189201. doi:10.5598/imafungus.2012.03.02.11

Ehrenfeld, J.G. 2003. Effects of exotic plant invasions on soil nutrient cycling processes. Ecosystems 6(6): 503-523. DOI: 10.1007/s10021-002-0151-3

Gehring, C. A., Ji, B., Fong, S. and T.G. Whitham. 2014. Differential feedback effects of arbuscular mycorrhizal fungi and other root endophytes in a Populus hybrid system. Botany 92:287-293. 
Goldberry, S., and Deckert, R. 2006. Comparison of mycorrhizal colonization frequency of Bromus tectorum and native grass species at Antelope Island State Park. NCUR 20, University of North Carolina-Asheville, NC. 20th National Conference on Undergraduate Research.

Hawkes, C. V., Belnap, J., D’Antonio, C., and Firestone, M.K. 2005. Arbuscular mycorrhizal assemblages in native plant roots change in the presence of invasive exotic grasses. Plant and Soil 281: 1-12: 369-380. DOI 10.1007/s11104-005-4826-3

Herrera, J., Khidir, H.H., Eudy, D.M., Porras-Alfaro, A., Natvig, D.O., and Sinsabaugh, R.L. 2010. Shifting fungal endophyte communities colonize Bouteloua gracilis: effect of host tissue and geographical distribution. Mycologia 102(5): 1012-1026. doi: 10.3852/09-264.

Hultine, K.R., Dudley, T.L., Koepke, D.F., Bean, D.W., Glenn, E.P., and Lambert, A.M. 2015. Patterns of herbivory-induced mortality of a dominant non-native tree/shrub (Tamarix spp.) in a southwestern US watershed. Biological Invasions 17(6): 1729-1742. doi: $10.1007 / \mathrm{s} 10530-014-0829-4$

Jumpponen, A. R.I. 2001. Dark septate endophytes. Are they mycorrhizal? Mycorrhiza 11:207211. doi: $10.1007 / \mathrm{s} 005720100112$.

Jumpponen, A. R. I., and Trappe, J.A. 1998. Dark septate endophytes: a review of facultative biotrophic root-colonizing fungi. New Phytologist 140(2) 295-310.

Khidir, H. H., Euly, D.M., Porras-Alfaro, A., Herrera, J., Natvig, D.O., and Sinsabaugh, R.L. 2010. A general suite of fungal endophytes dominate the roots of two dominant grasses in a semiarid grassland. Journal of Arid Environments 74(1): 35-42. 
doi:10.1016/j.jaridenv.2009.07.014

Klironomos, J.N. 2002. Feedback with soil biota contributes to plant rarity and invasiveness in communities. Nature 417: 67-70. doi:10.1038/417067a

Knapp, P.A. 1996. Cheatgrass (Bromus tectorum L.) dominance in the Great Basin Desert: History, persistence, and influences to human activities. Global Environmental Change 6(1): 37-52. http://dx.doi.org.libproxy.nau.edu/10.1016/0959-3780(95)00112-3.

Knapp, D.G., Pintye, A., and Kovács, G.M. 2012. The Dark Side Is Not Fastidious - Dark Septate Endophytic Fungi of Native and Invasive Plants of Semiarid Sandy Areas. PLoS ONE 7(2):e32570. doi: 1371/journal.pone.0032570.

Kuske, C. R., Ticknor, L.O., Miller, M.E., Dunbar, J.M., Davis, J.A., Barns, S.M., and Belnap, J. 2002. Comparison of soil bacterial communities in rhizospheres of three plant species and the interspaces in an arid grassland. Applied and Environmental Microbiology 68(4): 18541863. DOI: 10.1128/AEM.68.4.1854-1863.2002

Kohout, P., Sudová, R., Janousková, M., Ctvrtlíková, M., Hejda, M., Pánková, H., Slavíková, R., Stajerová, K., Vosátka, M., and Sykorová, Z. 2013. Comparison of commonly used primer sets for evaluating arbuscular mycorrhizal fungal communities: Is there a universal solution? Soil Biology and Biochemistry 68: 482- 493. doi: 10.1016/j.soilbio.2013.08.027

Lekberg, Y., Gibbons, S.M., Rosendahl, S., and Ramsey, P.W. 2013. Severe plant invasion can increase mycorrhizal fungal abundance and diversity. The ISME Journal 7: 1424-1433.

Lodge, D. M., Williams, S., MacIsaac, H.J., Hayes, K.R., Leung, B., Reichard, S., Mack, R.N., Moyle, P.B., Smith, M., Andow, D.A., Carlton, J.T., and McMichael, A. 2006. Biological 
invasions: recommendations for US policy and management. Ecological Applications 16(6): 2035-2054.

Mack, R. N., Simberloff, D., Lonsdale, W. M., Evans, H, Clout, M., and Bazzaz, F.A. 2000. Biotic invasions: causes, epidemiology, global consequences, and control. Ecological Applications 10:689-710.

Majewska, M. L., Blaszkowski, J., Nobis, M., Rola, K., Nobis, A., Lakimiec, D., Czachura, P., and Zubek, S. 2015. Root-inhabiting fungi in alien plant species in relation to invasion status and soil chemical properties. Symbiosis 65(3):1-15. doi: 10.1007/s13299-015-0324-4.

Mandyam, K., and Jumpponen, A. 2005. Seeking the elusive function of root-colonising dark septate endophytic fungi. Studies in Mycology 53: 173-189. doi: 10.3114/si.53.1.173.

Mandyam, K., and Jumpponen, A 2014. Unraveling the dark septate endophyte functions: insights from the Arabidopsis model. In Advances in Endophytic Research. Springer India 115-141. doi: 10.1007/978-81-322-1575-2_6.

Mapperson, R.R., Kotiw, M., Davis, R.A., and Dearnaley, J.D.W. 2013. The Diversity and Antimicrobial Activity of Preussia sp. Endophytes Isolated from Australian Dry Rainforests. Current Microbiology 6(1): 30- 37. doi:10. 1007/ s00284-013-0415-5

Massenssini, A.M., Bonduki, V.H.A., Tótola, Ferreira, F.A., and Costa, M.D. 2014. Arbuscular mycorrhizal associations and occurrence of dark septate endophytes in the roots of Brazilian weed plants. Mycorrhiza 24(2): 153-159. doi: 10.1007/s00572-013-0519-6

McCune, B. and M. J. Mefford. 2011. PC-ORD. Multivariate Analysis of Ecological Data. 
Version 6. MjM Software, Gleneden Beach, Oregon, U.S.A

McGonigle, T. P., Miller, M.H., Evans, D. G., Fairchild, G. L. and Swan, J. A. 1990. A new method which gives an objective measure of colonization of roots by vesicular-arbuscular mycorrhizal fungi. New Phytol. 115:495-501.

Mello, A., Napoli, C., Murat, C., Morin, E., Marceddu, G., and Bonafonte, P. 2011. ITS-1 versus ITS-2 pyrosequencing: a comparison of fungal populations in truffle grounds. Mycologia 103(6) 1184-1193. doi:10.3852/11-027.

Meinhardt, K. A. and Gehring, C.A. 2012. Disrupting mycorrhizal mutualisms: a potential mechanism by which exotic tamarisk outcompetes native cottonwoods. Ecol. Appl., 22:532549. doi: $10.1158 / 0008-5472$

Mousa, W.K., and Raizada, M.N. 2013. The diversity of anti-microbial secondary metabolites produced by fungal endophytes: and interdisciplinary perspective. Frontiers in Microbiology 65(4). doi: 10.3389/fmicb.2013.00065

Newsham, K.K. 2011. A meta-analysis of plant responses to dark septate root endophytes. New Phytol. 190(3):783-793. doi: 10.1111/j.1469-8137.2010.03611.x.

Norton, J. B., Monaco, T.A., Norton, J.M.,Johnson, D.A., and Jones, T.A. 2004. Soil morphology and organic matter dynamics under cheatgrass and sagebrush-steppe plant communities. Journal of Arid Environments 57(4): 445-466. doi:10.1016/S01401963(03)00104-6. 
Owen, S.M., Sieg, C.H., and Gehring, C.A. 2011. Seeding with native shrubs and the use of Imazapic herbicide on grazing lands affected by cheatgrass invasion. Invasive Plant Science and Management Journal 4(2):223-233. doi: 10.1614/IPSM-D-10-00054.1

Owen, S. M., Sieg, C.H., Johnson, N.C., and Gehring, C.A. 2013. Exotic cheatgrass and loss of soil biota decrease the performance of a native grass. Biological Invasions 15(11), 25032517. doi: 10.1007/s10530-013-0469-0.

Pimentel, D., Zuniga, R. and Morrison, D. 2005. Update on the environmental and economic costs associated with alien-invasive species in the United States. Ecological Economics 52(3): 273-288. doi:10.1016/j.ecolecon.2004.10.002

Porras-Alfaro, A., Herrera, J., Natvig, D.O., Lipinski, K., and Sinsabaugh, R.L. 2011. Diversity and distribution of soil fungal communities in a semiarid grassland. Mycologia 103(1): 1021. doi: 10.3852/09-297.

Pringle, A., Bever, J.D., Gardes, M., Parrent, J.L., Rillig, M.C., and Klironomos, J.N. 2009. Mycorrhizal symbioses and plant invasions. Annu Rev Ecol Evol Syst 40:699-715. doi: 10.1146/annurev.ecolsys.39.110707.173454.

R Core Team 2011. R: A language and environment for statistical computing. R Foundation for Statistical Computing, Vienna, Austria. ISBN 3-900051-07-0, URL http://www.Rproject.org/

Rillig, M.C., Wendt, S., Antonovics, J., Hempel, S., Kohler, J., Wehner, J., and Caruso, T. 2013. Interactive effects of root endophytes and arbuscular mycorrhizal fungi on an experimental plant community. Oecologia 174: 263-270. doi: 10.1007/s00442-013-2759-8 
Rohland, N. and Reich, D. 2012. Cost-effective, high-throughput DNA sequencing libraries for multiplexed target capture. Genome Research 22: 939-946. doi:10.1101/gr.128124.1.

Rosendahl S., and Stukenbrock, E.H. 2004. Community structure of arbuscular mycorrhizal fungi in undisturbed vegetation revealed by analyses of LSU rDNA sequences. Molecular Ecology, 13: 3179-3186. doi: 10.1111/j.1365-294X.2004.02295.x

Rout, M.E., Chrzanowski, T.H., Westlie, T. K., DeLuca, T. H., Callaway, R. M., and Holben, W. E. 2013. Bacterial endophytes enhance competition by invasive plants. American Journal of Botany 100(9): 1726 doi: 10.3732/ajb.1200577.

Scervino, J. M., Gottlieb, A., Silvani, V.A., Pérgola, M., Fernández, L., and Godeas, A.M. Exudates of dark septate endophyte (DSE) modulate the development of the arbuscular mycorrhizal fungus (AMF) Gigaspora rosea. Soil Biology and Biochemistry 41(8): 17531756. doi: 10.1016/j.soilbio.2009.04.021.

Saks, Ü., Davidson, J., Öpik, M., Vasar, M., Moora, M., and Zobel, M. 2013. Root-colonizing and soil-borne communities of arbuscular mycorrhizal fungi in a temperate forest and understory. Botany 92(4): 277-285. doi:10.1139/cjb-2013-0058.

Scherpenisse, D.S. 2009. Mycorrhizae In Sagebrush-Steppe Community Restoration: Mycorrhizal Dependency Of Invasive And Native Grasses With Intraspecific And Interspecific Competition. M.Sc. Thesis. Utah State University, UT.

Schittko, C., and Wurst, S. 2014. Above- and belowground effects of plant-soil feedback from exotic Solidago canadensis on native Tanacetum vulgare. Biological Invasions 16: 14651479. doi: 10.1007/s10530-013-0584-y 
Siegel, M.R., Latch, G.C.M., and Johnson, M.C. 1986. Acremonium Fungal Endophytes of Tall Fescue and Perennial Ryegrass: Significance and Control. Plant Disease 69(2):179-181.

Stinson, K.A., Campbell, S.A., Powell, J.R., Wolfe, B.E., Callaway, R.M., Thelen, G.C., Hallett, S.G., Prati, D., and Klironomos, J.N. 2006 Invasive plant suppresses the growth of native tree seedlings by disrupting belowground mutualisms. Plos Biology 4(5): e140. doi:10.1371/journal.pbio.0040140.

Tamura, M., and Tharayil, N. 2014. Plant litter chemistry and microbial priming regulate the accrual, composition and stability of soil carbon in invaded ecosystems. New Phytologist 203(1): 110-124. doi: 10.1111/nph.12795.

Vandenkoornhuyse, P., Husband, R., Daniell, J.T, Watson, I.J., Duck, J.M., Fitter, A.H., and Young, J.P.W. 2002. Arbuscular mycorrhizal community composition associated with two plant species in a grassland ecosystem. Molecular Ecology 11(8):1555-1564.

Vogelsang, K.M, and Bever, J.D. 2009. Mycorrhizal densities decline in association with nonnative plants and contribute to plant invasion. Ecology 90(2); 399-407.

Weber, C. F., King, G.M., and Aho, K. 2015. Relative abundance of and composition within fungal orders differ between cheatgrass (Bromus tectorum) and sagebrush (Artemisia tridentata)-associated soils. PLoS ONE 10(1): e0117026.

doi:10.1371/journal.pone.0117026 
Table 1. Results of indicator species analysis comparing DSF communities in roots and soil of invaded and non-invaded sites and cheatgrass, rice grass or sagebrush in invaded sites.

\begin{tabular}{|c|c|c|c|c|}
\hline Source & OTU & Indicator of & IV* & p-value \\
\hline \multirow[t]{12}{*}{ ROOTS } & Leptosphaerulina chartarum & Invaded site & 50 & 0.015 \\
\hline & Leptosphaeria sydowii & Invaded site & 75 & 0.023 \\
\hline & Massarina sp JP_2013 & Invaded site & 73 & 0.029 \\
\hline & Alternaria alternata & Invaded site & 65 & 0.003 \\
\hline & Alternaria soliaridae & Invaded site & 42 & 0.038 \\
\hline & Alternaria sp 3 MU_2012 & Invaded site & 50 & 0.023 \\
\hline & Pleosporaceae sp & Invaded site & 68 & 0.009 \\
\hline & Preussia $s p$ & Non-invaded site & 68 & 0.046 \\
\hline & Uncultured Pleosporales & Cheatgrass & 82 & 0.008 \\
\hline & Leptosphaerulina chartarum & Rice grass & 75 & 0.034 \\
\hline & Pleosporales sp. & Rice grass & 69 & 0.051 \\
\hline & Corniothyrium nitidae & Sagebrush & 64 & 0.042 \\
\hline \multirow[t]{10}{*}{ SOIL } & Leptosphaerulina chartarum & Invaded site & 91 & 0.0004 \\
\hline & Leptosphaeria sydowii & Invaded site & 68 & 0.032 \\
\hline & Phaeosphaeria spartinae & Invaded site & 61 & 0.038 \\
\hline & Alternaria alternata & Invaded site & 94 & 0.0002 \\
\hline & Alternaria sp 3 MU_2012 & Invaded site & 73 & 0.0012 \\
\hline & Pleosporaceae sp. & Invaded site & 69 & 0.044 \\
\hline & Macrospora scirpicola & Non-invaded site & 99 & 0.0002 \\
\hline & Westerdykella ornata & Non-invaded site & 91 & 0.0002 \\
\hline & Pleosporales sp. & Non-invaded site & 76 & 0.029 \\
\hline & Venturia fraxini & Non-invaded site & 71 & 0.0054 \\
\hline
\end{tabular}

* Indicator value 


\section{Figure Legends}

Figure 1. Average root colonization by DSF (A) and average number of observed OTUs in roots (B) and rhizosphere soil (C) of rice grass (RG), and sagebrush (SB) in invaded and non-invaded sites and cheatgrass $(\mathrm{CG})$ in invaded sites. Error bars represent standard errors. See text for results of statistical analyses.

Figure 2. Rarefaction curves comparing observed DSF OTU richness (+/- SE) of roots and rhizosphere soil for combined sagebrush and rice grass samples, and the numbers of shared and unique OTUs in root and rhizosphere soil communities (insert).

Figure 3. PCoA plots of Bray-Curtis distances between root (top panel) and rhizosphere soil (bottom panel) associated DSF of rice grass and sagebrush in invaded and non-invaded sites.

Figure 4. PCoA plots of Bray-Curtis distances between root (top panel) and rhizosphere (bottom panel) associated DSF of cheatgrass $(\mathrm{CG})$, ricegrass $(\mathrm{RG})$, and sagebrush $(\mathrm{SB})$ in the invaded site. 
Figure 1
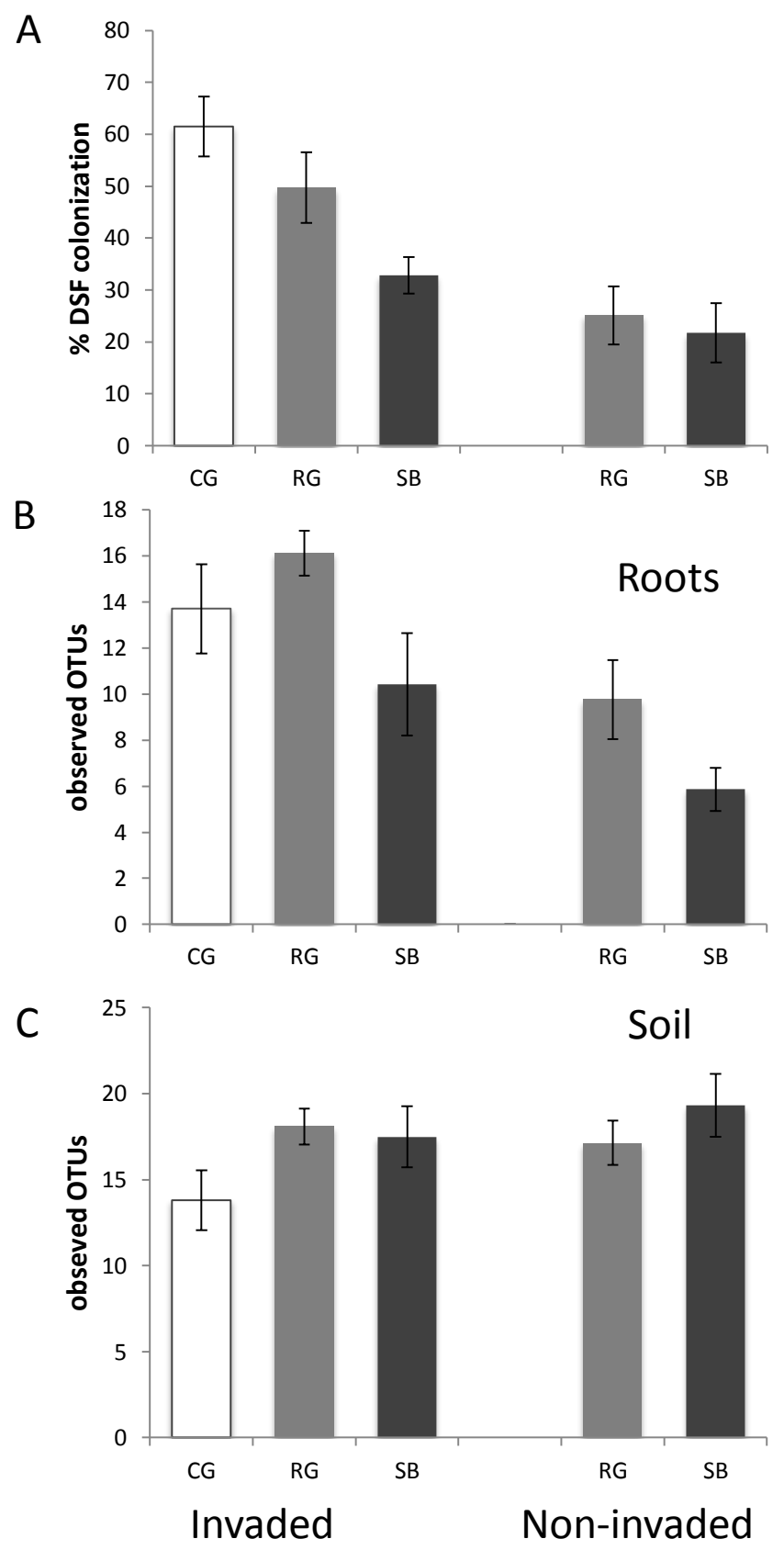
Figure 2

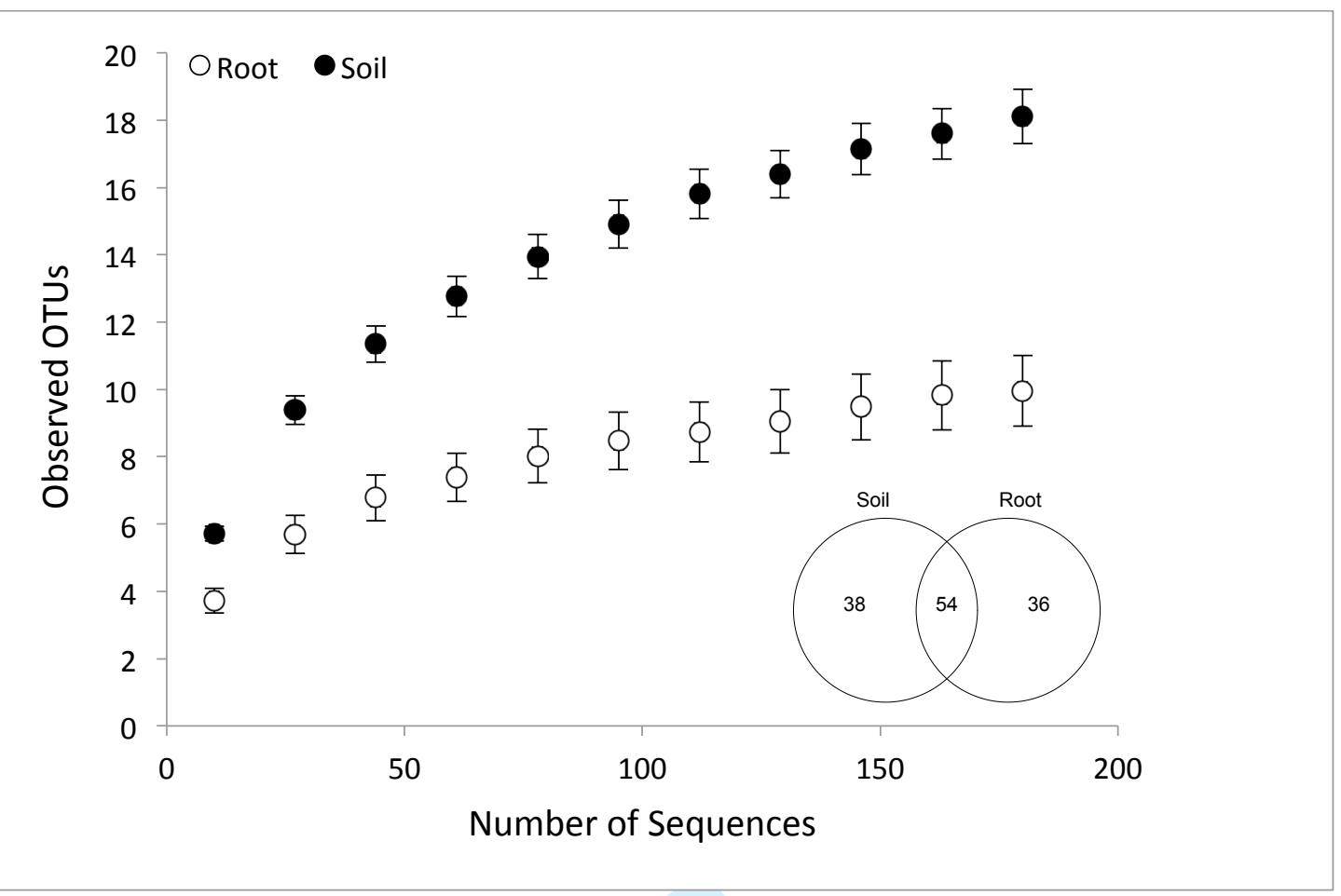


Figure 3
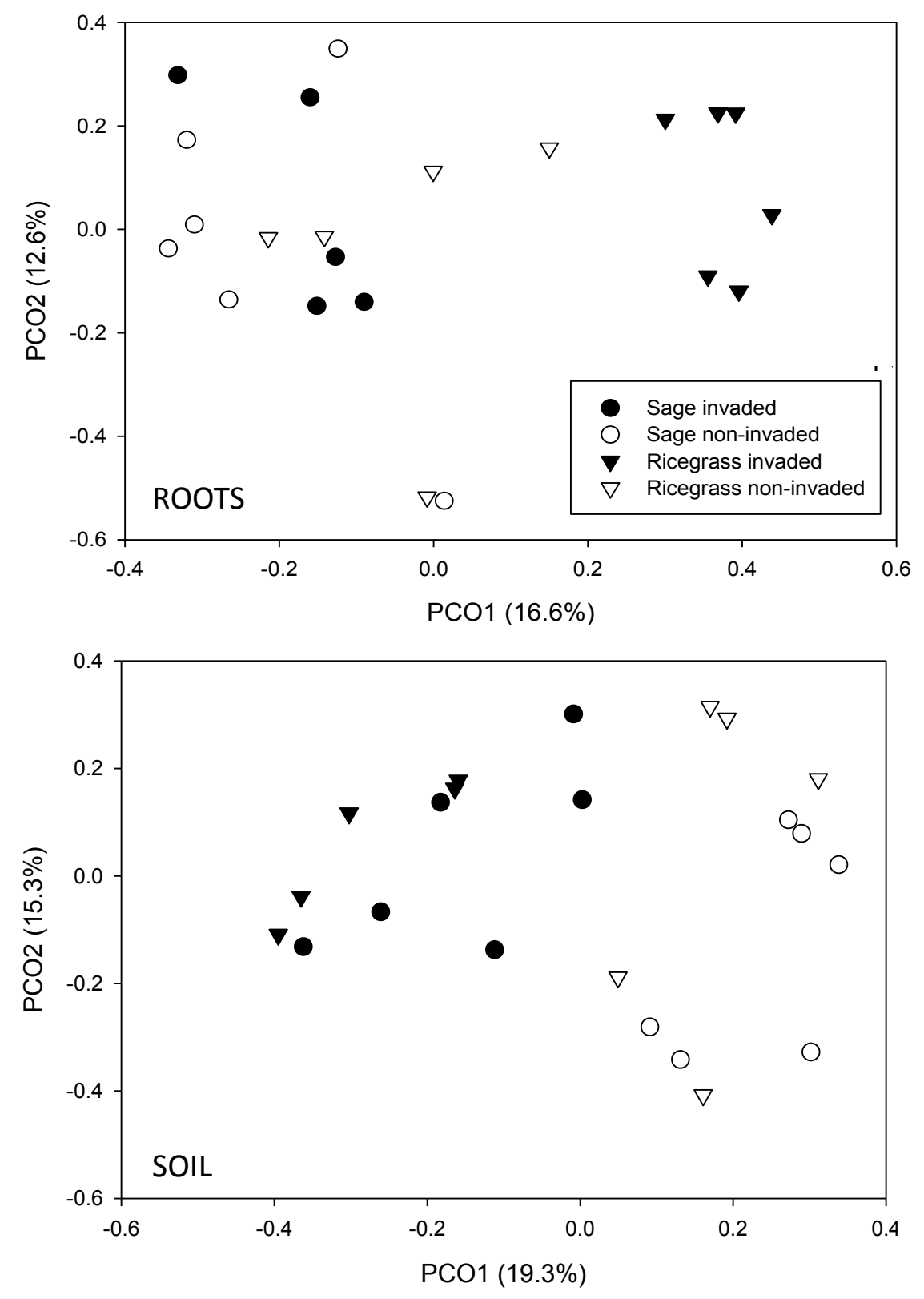
Figure 4
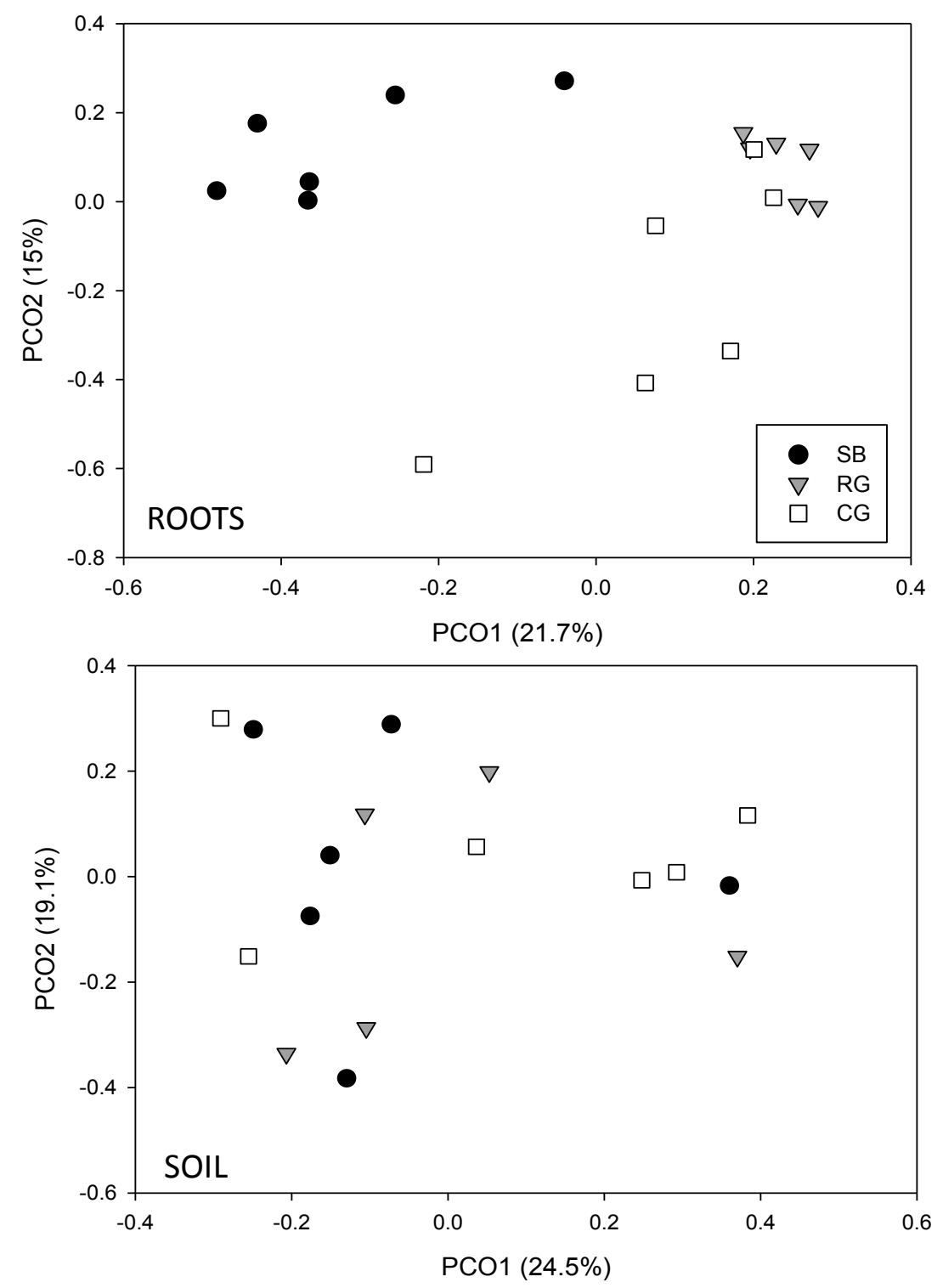